Article

\title{
Yield, Decomposition, Mineralization and Nitrification of Annual Legumes in an Oxisol
}

\author{
Rebecca Tirado-Corbalá ${ }^{1, *}$, Litza Y. López-Ramos ${ }^{2}$, Elide Valencia-Chin ${ }^{1}$ and \\ Elvin Román-Paoli ${ }^{1}$
}

1 Agro-Environmental Sciences Department, University of Puerto Rico-Mayagüez, Box 9000, Mayagüez, PR 00681, USA; elide.valencia@upr.edu (E.V.-C.); elvin.roman@upr.edu (E.R.-P.)

2 Former Student, Agro-Environmental Sciences Department, University of Puerto Rico-Mayagüez, Box 9000, Mayagüez, PR 00681, USA; litza.lopez@upr.edu

* Correspondence: rebecca.tirado@upr.edu or rebeccatiradocorbala@gmail.com; Tel.: +1-787-370-9179

Received: 12 August 2018; Accepted: 31 October 2018; Published: 2 November 2018

\begin{abstract}
Knowledge about seasonal and litter bag soil position effects on litter decomposition ( $k$ value), mineralization and nitrification rate of annual legumes in Puerto Rico is limited. This study determined dry matter yield (DMY), $k$ value of litter bags placed below and above the soil surface, mineralization and nitrification rates of Lablab purpureus cv. "Rongai" and Mucuna pruriens (Velvet bean) seeded in the wet and dry season in Oxisol soils (Typic Eustrustox). There was an interaction $(p<0.05)$ for season and legumes on DMY, $k$ value and N content. "Rongai" DMY was higher for the dry than wet season while Velvet bean had an opposite seasonal response. Higher $k$ value occurred in the wet season for legumes, but "Rongai" had higher $k$ than Velvet bean. For both legumes, $\mathrm{N}$ content was higher on litter bag placed below-ground in both seasons. However, in the wet season, there was less $\mathrm{N}$ in the above ground litter position. Higher inorganic $\mathrm{N}$ was observed at 90 days of soil incubation (DOI) suggesting that $\mathrm{N}$ was not available prior to $42 \mathrm{DOI}$. Nitrification rate was higher for "Rongai" at 22 DOI and lower at 42 and 90 DOI for both legumes. Both legumes enhanced inorganic N, but, regardless of season, Rongai supplied nutrients to the soil faster than Velvet bean. "Rongai" because of its higher $k$ value than Velvet bean is recommended for fast growing row or vegetable crops in Puerto Rico.
\end{abstract}

Keywords: cover crops; lablab; legumes; mineralization; nitrification; velvet bean; yield

\section{Introduction}

In Puerto Rico, annual leguminous cover crops such as lablab (Lablab purpureus (L.) Sweet) cv. "Rongai" and Velvet bean (Mucuna pruriens (L.) DC.) are used as fallow crops to provide soil cover, smother weeds and increase soil organic matter prior to a main crop planting maize (Zea mays L.). Leguminous cover crops have been demonstrated to increase soil organic matter [1], soil aggregate stability, reduce erosion [2], increase plant diversity, and pest control. Both Velvet bean and "Rongai" are productive and good nitrogen fixers, with Velvet bean producing 6-7-ton ha ${ }^{-1}$ of dry matter (DM) annually and 3.6-ton ha ${ }^{-1}$ of seeds [3] and $90-100 \mathrm{~kg} \mathrm{~N} \mathrm{ha}^{-1}$ of fixed $\mathrm{N}$ [4]. Meanwhile, lablab has been reported to produce 6.2-ton ha ${ }^{-1}$ of DM and $50 \mathrm{lbs} \mathrm{N}$ ton $^{-1}$ [5].

Decomposition and nutrient release of tropical leguminous leaves are well documented [6]. Plant parts often show different rates of decomposition, the leaves having faster decomposition and $\mathrm{N}$ release than mixture of leaves or stems, and the mixtures and faster decomposition than stems alone [7]. Decomposition and $\mathrm{N}$ release are also affected by quality and quantity of the residue, soil humidity, temperature, biological activity, texture, and soil acidity [8]. The litterbag technique is most widely used for leaf and stem decomposition where standard quantities of plant parts are 
enclosed in nylon-mesh bags (incubated below or above ground in the field) and weight and nutrient loss monitored weekly by retrieval of the litterbags [9].

In the soil, organic N represents $97-98 \%$ of total $\mathrm{N}$ and is not available for plants. Only $2-3 \%$ of TN is available for plants in the inorganic form [1]. Depending on the quantity and quality of leguminous residues and soil $\mathrm{pH}$, total $\mathrm{N}$ in the top layer of the soil may increase [10] and soil OM mineralization occur [11]. The microbiological process can limit nitrification rates and ammonium $\left(\mathrm{NH}_{4}^{+}\right)$and nitrate $\left(\mathrm{NO}_{3}{ }^{-}\right)$distribution in the soil profile [11,12]. Other factors (i.e., temperature, aeration, soil humidity) can also limit $\mathrm{N}$ mineralization and nitrification in the soil [13]. The objectives of this research were to: (i) assess dry matter yield (DMY), leaves and petiole decomposition and $\mathrm{N}$ content of Velvet bean and "Rongai" through the dry and wet season and (ii) determine mineralization and nitrification rates of Velvet bean and "Rongai" on an Oxisol.

\section{Materials and Methods}

\subsection{Study Area}

\section{Experimental Area and Description}

Two studies were conducted at the Agricultural Experiment Substation (AES) of Isabela, Puerto Rico, located in the northwest of the island (18.46 Latitude and -67.05 Longitudes) at $120 \mathrm{~m}$ above sea level. Both experiments were established in Oxisol soils of the Coto series (very-fine, kaolinitic, isohyperthermic Typic Eustrustox) [14]. Mean annual average precipitation for the past 20 years (before 2009) was $1639 \mathrm{~mm}$ (Figure 1); May being the rainy and February the driest month, with an average mean temperature of $29^{\circ} \mathrm{C}$.

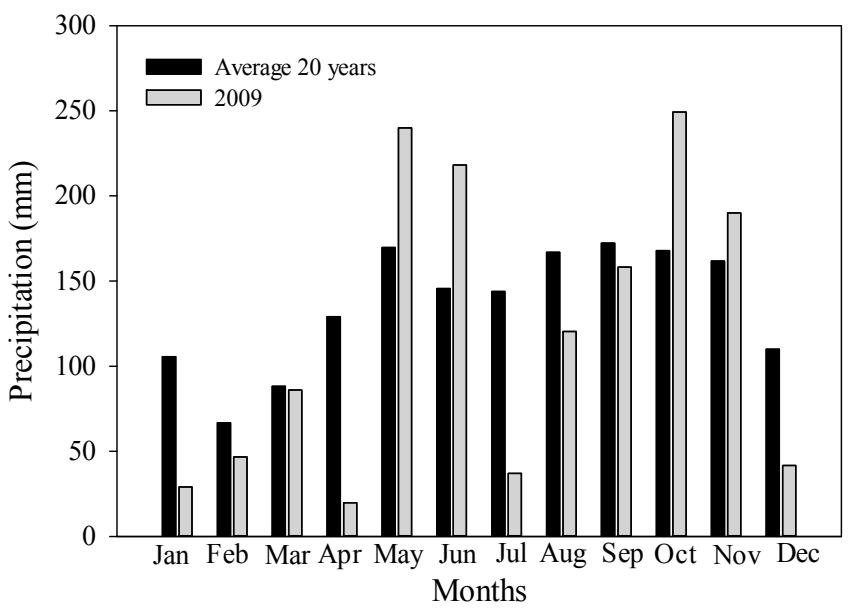

Figure 1. Average monthly precipitation in 2009 versus average monthly precipitation from the past 20 years in the Sub-Agricultural Experiment Station of Isabela, Puerto Rico.

The field experiment consisted of two annual legumes ("Rongai" and Velvet bean), two planting seasons (dry and wet) and two litterbag placements (below and aboveground) in a Randomized Complete Block (RCBD) with four replicates. A control plot (bare plot) was not included as treatment in this study because of the rapidly colonizing invasive Johnson grass (Sorghum halepense (L.) Pers.) present. The "Rongai" and Velvet bean were sowed on well-prepared seedbeds. Seeds were sown at $2.4 \mathrm{~cm}$ soil depth in $60 \mathrm{~cm}$ rows and $15 \mathrm{~cm}$ between plants in $525 \mathrm{~m}^{2}$ plots at a seeding density of $10 \mathrm{~kg} \mathrm{ha}^{-1}$ on 23rd December 2008 and on 19th June 2009, for the dry and wet season, respectively. Plots were irrigated the first three days to promote seed germination and no fertilization or weed control during the experimental period was needed.

After 90 days, for dry and wet season, three samples (in $1.5 \mathrm{~m}^{2}$ area) every $24 \mathrm{~m}$ in the central rows were harvested to ground level. Samples harvested were weighed (fresh weight) and oven dried at $60{ }^{\circ} \mathrm{C}$ for forty-eight hours and used to determined DMY $\left(\mathrm{kg} \mathrm{ha}^{-1}\right)$. A subset of dried samples 
(500 g) was ground in a Willey mill to pass a 1-mm screen and used to determine total N [15] at the United States Department of Agriculture, Agricultural Research Service, Tropical Agricultural Research Station (USDA-ARS-TARS) in Mayagüez, Puerto Rico. In addition, soil samples $(15 \mathrm{~cm})$ from the experimental plots were collected to determined $\mathrm{NO}_{3}{ }^{-}-\mathrm{NO}_{2}{ }^{-}$using the exchangeable ammonium, nitrate and nitrite methods described by Sparks [16].

Representative leaf and petiole samples from "Rongai" and Velvet bean were also harvested at 90 days from experimental plots and used for the decomposition rate study. Twelve nylon-mesh bags (six bags for above and belowground position) of $550 \mathrm{~cm}^{2}(25 \mathrm{~cm}$ long $\times 22 \mathrm{~cm}$ wide) were placed at $6 \mathrm{~m}$ from each other in each experimental unit. For the dry season, the nylon bags were packed with $15 \mathrm{~g}$ of leaves and were increased in the wet season to $25 \mathrm{~g}$. Litterbags at the above- and below-ground position (buried at $10 \mathrm{~cm}$ soil depth) were tied to PVC tubes (to avoid removal by rodents). All of the litterbags were buried on the same day approximately $15 \mathrm{~cm}$ from each bag. Every two weeks, two bags from each position and plot were collected to determine wet weight, dry weight (after drying at $60{ }^{\circ} \mathrm{C}$ for $72 \mathrm{~h}$ ) and decomposition rate. The decomposition rate was determined using the decomposition constant $(k)$. The $k$ was estimated using the first order exponential equation of Waider and Lang [17]:

$$
L_{R} / L_{f}=\mathrm{e}^{-k t}
$$

where:

$L_{R}=$ Remaining weight at certain time,

$L_{f}=$ Initial weight at zero time,

$t=$ Sampling time interval ( $L_{R}$ express in weeks),

$k=$ Decomposition constant,

$\mathrm{e}=$ Base of natural logarithm.

For study two, both "Rongai" and Velvet bean were established on 2nd February 2010 in a RCBD with four replicates [eight experimental plot of $72 \mathrm{~m}^{2}$ (18 $\mathrm{m}$ long $\times 4 \mathrm{~m}$ wide) each]. The establishment of the legumes followed the same procedure described in study 1 . The experimental field used for this study was under guinea grass (Megathyrsus maximus) pastures for several years. For the incubation study, one week after planting, six PVC tubes $(25.4 \mathrm{~cm}$ long $\times 5.1 \mathrm{~cm}$ wide) were inserted in each experimental plot, leaving outside (without insertion) approximately $5 \mathrm{~cm}$ of the PVC tube. Two of the six PVC tubes were removed from each experimental plot at 22, 42 and 90 days of incubation (DOI). Immediately after removing the PVC tubes, soil core samples were placed in a plastic bag and refrigerated.

Ammonium $\left(\mathrm{N}-\mathrm{NH}_{4}{ }^{+}\right)$and nitrate $\left(\mathrm{N}^{-\mathrm{NO}_{3}}{ }^{-}\right)$analyses were performed at the USDA-ARS-TARS in Mayagüez, Puerto Rico. The $\mathrm{NO}_{3}{ }^{-}-\mathrm{NO}_{2}{ }^{-}$was determined using the exchangeable $\mathrm{N}^{-} \mathrm{NH}_{4}{ }^{+}, \mathrm{NO}_{3}{ }^{-}-$ and $\mathrm{NO}_{2}{ }^{-}$methods described by Sparks [16]. Soil net mineralization and nitrification were calculated using the formulas described by Robertson et al. [18]:

Net Mineralization $=\left[\left(\right.\right.$ Nitrate $_{\mathrm{f}}+$ Ammonium $\left._{\mathrm{f}}\right)-\left(\right.$ Nitrate $_{0}+$ Ammonium $\left.\left._{0}\right)\right] /$ T days,

where:

Net Mineralization $=$ net mineralization rate, express in $\mathrm{mg} \mathrm{N} \mathrm{kg}^{-1} \mathrm{~d}^{-1}$,

Nitrate $_{\mathrm{f}}=$ final concentration of nitrate, express in $\mathrm{mg} \mathrm{N}^{-\mathrm{NO}_{3}}{ }^{-} \mathrm{g}^{-1}$ soil $^{-1}$,

Ammonium $_{\mathrm{f}}=$ final concentration of ammonium, express in $\mathrm{mg} \mathrm{N}^{-\mathrm{NH}_{4}}{ }^{+} \mathrm{g}^{-1}$ soil $^{-1}$,

Nitrate $_{0}=$ initial concentration of nitrate, express in $\mathrm{mg} \mathrm{N}^{-\mathrm{NO}_{3}}{ }^{-} \mathrm{g}^{-1}$ soil $^{-1}$,

Ammonium $_{0}=$ initial concentration of ammonium, express in $\mathrm{mg} \mathrm{N}^{-\mathrm{NH}_{4}}{ }^{+} \mathrm{g}^{-1}$ soil $^{-1}$,

$\mathrm{T}$ days $=$ incubation time, express in days

$$
\text { Net Nitrification }=\left[\left(\text { Nitrate }_{\mathrm{f}}-\text { Nitrate }_{0}\right) /\right. \text { T days, }
$$


where:

Net Nitrification $=$ net nitrification rate, express in $\mathrm{mg} \mathrm{N}-\mathrm{NO}_{3}{ }^{-} \mathrm{kg}^{-1} \mathrm{~d}^{-1}$,

In addition, soil inorganic $\mathrm{N}$ was calculated for each sample with the following formula:

$$
\mathrm{N}_{\text {inorganic }}=\text { Ammonium }\left(\mathrm{N}-\mathrm{NH}_{4}{ }^{+}\right)+\text {Nitrate }\left({\mathrm{N}-\mathrm{NO}_{3}}^{-}\right) \text {. }
$$

\subsection{Statistical Analysis}

Yield, $k$ constant, $\mathrm{N}$ content, and C:N ratio were analyzed using the General Lineal Model (GML; SAS program, Carry, NC, USA) [19] and means separation when significant was conducted using with Tukey's at $(p<0.05)$. Soil inorganic $\mathrm{N}$, mineralization and nitrification rate of $\mathrm{N}$ were also analyzed using the procedures described above.

\section{Results}

\subsection{Yield, Decomposition Rate, and N Content in Leguminous Leaves}

Table 1 shows the effect of planting season (dry and wet) for yield, $k$ constant, total $\mathrm{N}$, and C:N ratio for "Rongai" and Velvet bean. There was an interaction $(p=0.009)$ for planting season and legumes for yield, indicating that legumes were affected by season. Yield was higher for "Rongai" in the dry season (5535 kg ha $\left.{ }^{-1}\right)$ compared to the wet season $\left(4263 \mathrm{~kg} \mathrm{ha}^{-1}\right)$, while Velvet bean had an opposite seasonal response (3785 and $4155 \mathrm{~kg} \mathrm{ha}^{-1}$ for the dry and wet season, respectively) (Table 1). In addition, both legumes had a higher $k$ constant in the wet season, where "Rongai" had 1.5 times higher $k$ values than Velvet bean, even though no statistical difference was found $(p>0.05)$. For $\mathrm{N}$ concentration, no interaction $(p>0.05)$ of legume species by season was observed, indicating that these treatments act independently. However, significant differences $(p<0.05)$ between dry and wet period on DM-N concentration were found. Nitrogen content differed by season $(p<0.0001)$ with $53.5 \mu \mathrm{g} \mathrm{N} \mathrm{g}{ }^{-1}(2.78 \%$ of $\mathrm{N})$ and $39.7 \mu \mathrm{g} \mathrm{N} \mathrm{g}{ }^{-1}(2.06 \%$ of $\mathrm{N})$, for "Rongai" in the dry and wet seasons, respectively. However, there was no season effect for Velvet bean (mean $63.7 \mu \mathrm{g} \mathrm{N} \mathrm{g}{ }^{-1}=3.31 \%$ of N) or differences in $\mathrm{C} / \mathrm{N}$ ratio for both legumes.

Table 1. Average values of yield, $k$ constant, $\mathrm{N}$ concentration and C:N ratio for the interaction of season and cover crops species growing in an Oxisol in the Agricultural Experiment Substation of Isabela, Puerto Rico.

\begin{tabular}{ccccccccc}
\hline \multirow{2}{*}{ Season } & \multicolumn{2}{c}{ Yield $\left(\mathbf{k g ~ h a}^{-\mathbf{1}}\right)$} & \multicolumn{2}{c}{$\mathbf{k}\left(\mathrm{day}^{\mathbf{- 1}}\right)$} & \multicolumn{2}{c}{$\mathbf{N}\left(\mu \mathrm{g}^{-\mathbf{1}}\right)$} & \multicolumn{2}{c}{ C:N ${ }^{\mathbf{2}}$ Ratio } \\
\cline { 2 - 8 } & Rongai & $\begin{array}{c}\text { Velvet } \\
\text { Bean }\end{array}$ & Rongai & $\begin{array}{c}\text { Velvet } \\
\text { Bean }\end{array}$ & Rongai & $\begin{array}{c}\text { Velvet } \\
\text { Bean }\end{array}$ & Rongai & $\begin{array}{c}\text { Velvet } \\
\text { Bean }\end{array}$ \\
\hline Dry & $5535 \mathrm{a}^{1}$ & $3785 \mathrm{a}$ & 0.079 & 0.074 & $53.5 \mathrm{a}$ & $64.7 \mathrm{a}$ & 10.9 & 11.1 \\
Wet & $4263 \mathrm{~b}$ & $4155 \mathrm{~b}$ & 0.262 & 0.175 & $39.7 \mathrm{~b}$ & $62.6 \mathrm{a}$ & 13.2 & 10.2 \\
\hline
\end{tabular}

1 Lower case letter represents difference between seasons for each analyzed parameter at $p<0.05$.

${ }^{2} k=$ Decomposition rate; $\mathrm{N}=$ Nitrogen concentration; $\mathrm{C}: \mathrm{N}=$ Carbon and nitrogen ratio.

There was an interaction $(p<0.05)$ for $\mathrm{N}$ between bag position and season (Table 2). Higher $\mathrm{N}$ was observed below ground in both seasons, but there was 2.5 times less $\mathrm{N}$ above ground during the wet season (Table 2). In addition, there was an $\mathrm{N}$ interaction for time of sampling by litter-bag position (Figure 2a) and time of sampling by season (Figure 2b). Tissue $\mathrm{N}$ concentrations decreased with time (Figure 2a) and this decline was more obvious in above-ground compared to below-ground samples. As observed in Figure $2 \mathrm{~b}$, a higher $\mathrm{N}$ concentration was encountered in the first eight weeks during the dry season and at 10 and 12 weeks during the wet season. 
Table 2. Average tissue level values of $\mathrm{N}$ content for the interaction of bag position and season for two cover crops species in an Oxisol in the Agricultural Experiment Substation of Isabela, Puerto Rico.

\begin{tabular}{ccc}
\hline \multirow{2}{*}{ Position } & \multicolumn{2}{c}{$\mathbf{M g ~ g}^{-1}$} \\
\cline { 2 - 3 } & Dry & Wet \\
\hline Above ground & $57.2 \mathrm{~b}^{1}$ & $25.2 \mathrm{~b}$ \\
Below ground & $61.0 \mathrm{a}$ & $77.0 \mathrm{a}$ \\
\hline
\end{tabular}

${ }^{1}$ Lower case letter represents difference between positions for each analyzed parameter at $p<0.05$.

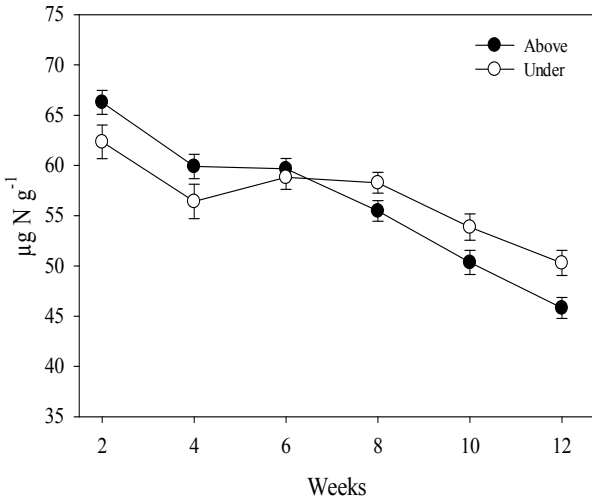

(a)

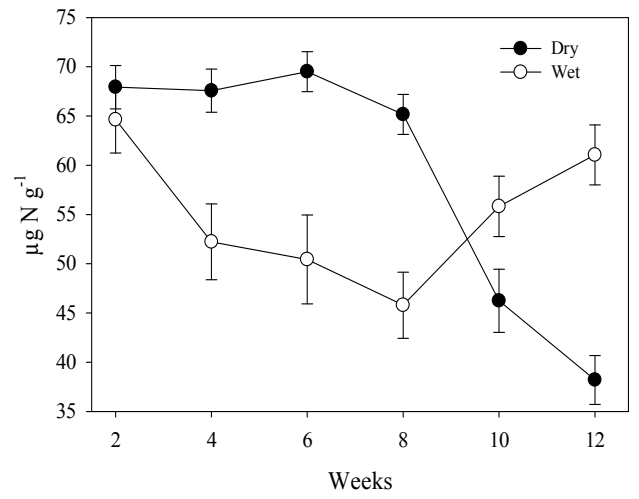

(b)

Figure 2. Mean average $\mathrm{N}$ content interaction of (a) time of sampling by bag position and (b) time of sampling by seasons for both legumes in an Oxisol. Vertical lines represent the standard errors.

\subsection{Mineralization and Net Nitrification of $N$ in the Soil}

There was a significant difference $(p<0.05)$ between incubation days for soil inorganic $\mathrm{N}$ (Figure 3 ). Higher inorganic $\mathrm{N}\left(\sim 795 \mathrm{mg} \mathrm{N} \mathrm{kg}^{-1}\right)$ was observed at $90 \mathrm{DOI}$, but no difference was observed between day 22 and $42\left(\sim 175 \mathrm{mg} \mathrm{N} \mathrm{kg}^{-1}\right)$, indicating that $\mathrm{N}$ was not available before 42 days.

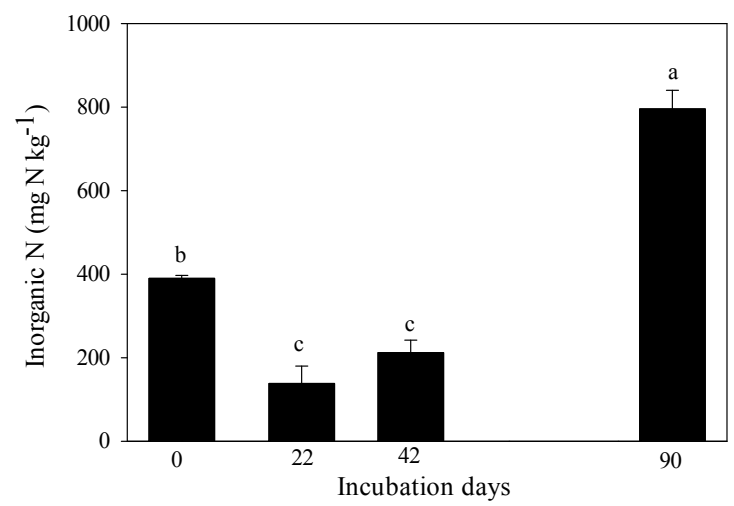

Figure 3. Mean average values of soil inorganic $\mathrm{N}$ content from 0 to 90 days of incubation. Vertical lines represent the standard errors and lower case letter represents difference between the incubation days.

Figure 4a shows differences $(p<0.05)$ between the days of incubation for soil $\mathrm{N}$ net mineralization $\left(-11\right.$ to $\left.5 \mathrm{mg} \mathrm{kg}^{-1} \mathrm{~d}^{-1}\right)$. The negative values encountered on 22 and 42 DOI are indicative of immobilization. However, there was an interaction between legumes and incubation days for soil $\mathrm{N}$ net nitrification, indicative that both factors act dependently on each other. Higher soil $\mathrm{N}$ nitrification was observed on "Rongai" at 22 DOI $\left(\sim 1.24 \mathrm{mg} \mathrm{kg}^{-1} \mathrm{~d}^{-1}\right)$. The lowest $\mathrm{N}$ net nitrification was observed at 42 and 90 DOI for both legumes ( -2.25 and $-0.79 \mathrm{mg} \mathrm{kg}^{-1} \mathrm{~d}^{-1}$, respectively). Mineral $\mathrm{N}$ analysis was $80 \%$ of inorganic $\mathrm{N}\left(\mathrm{NH}_{4}{ }^{+}-\mathrm{N}\right)$. The negative values observed at 42 and $90 \mathrm{DOI}$ are due to high concentrations of $\mathrm{NH}_{4}{ }^{+}-\mathrm{N}$ during the mineralization process. 


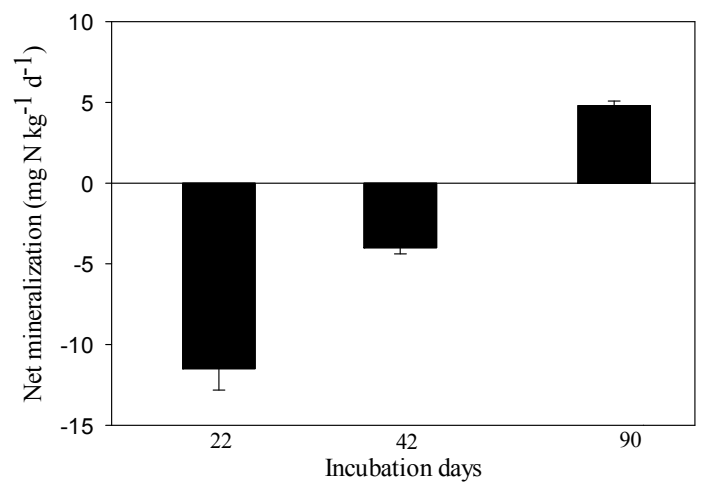

(a)

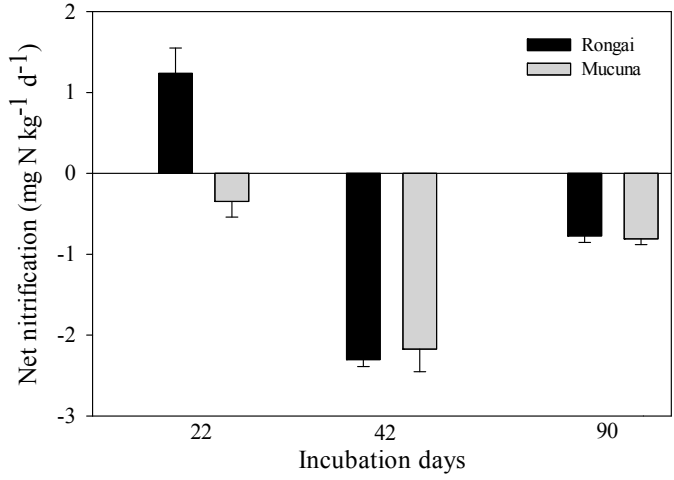

(b)

Figure 4. Average values of (a) N net mineralization in the soil during 90 days of incubation and (b) $\mathrm{N}$ net nitrification for the interaction of annual cover crops and incubation days. Vertical lines represent the standard errors.

\section{Discussion}

\subsection{Yield, Decomposition Rate and N Content}

"Rongai" had around 30\% higher dry matter yield (DMY) than Velvet bean in the dry season, and similar DMY $\left(\sim 4200 \mathrm{~kg} \mathrm{ha}^{-1}\right)$ during the wet season. Colbert et al. [20] reported DMY of 3200 and $3000 \mathrm{~kg} \mathrm{ha}^{-1}$ for "Rongai", for May and August plantings, respectively on the same soil type (Coto soil series), and much lower DMY than those found in our study for the wet season planting (June). Shehu et al. [21] reported similar DMY (5550 $\left.\mathrm{kg} \mathrm{ha}^{-1}\right)$ for "Rongai" during the dry and wet periods in the Sudan Savannah in Nigeria. While, Anthofer and Kroschel [22] reported DMY of Velvet bean (4003 $\mathrm{kg} \mathrm{ha}^{-1}$ ) consistent with to those reported in our study.

Litter decomposition ( $k$ values) for both legumes show a first order response, indicating that $k$ values are affected by humidity and temperature. In general, $k$ values $(0.262$ and 0.175 for "Rongai and Velvet bean, respectively) were higher during the wet season. The higher $k$ value during the wet season for both legumes are due to higher rainfall (554 versus $162 \mathrm{~mm}$ in the wet and dry season, respectively) and five degrees higher in temperature $\left(30.3\right.$ versus $24.5^{\circ} \mathrm{C}$, in the wet versus the dry season). In the wet season, Poffenbarger et al. [23] attributed legume decomposition being much higher when moisture was higher.

Nitrogen concentration was higher during the dry season $(59.1 \mu \mathrm{g} \mathrm{N} \mathrm{g}=3.07 \%$ of $\mathrm{N})$ compared the wet season $\left(51.2 \mu \mathrm{g} \mathrm{N} \mathrm{g}^{-1}=2.78 \%\right.$ of $\left.\mathrm{N}\right)$. In addition, there were differences between annual legumes; Velvet bean $(3.43 \%$ of $\mathrm{N})$ percentage $\mathrm{N}$ was higher compared to "Rongai" $(2.42 \%$ of $\mathrm{N})$ in both seasons. Our results are similar to those found by Odhiambo [24] with both annual legumes; $2.9 \%$ and $2.3 \%$ for Velvet bean and "Rongai", respectively. Higher concentrations of N were found for Velvet bean compared with "Rongai". Velvet bean N concentration $(\sim 3.43 \%$ of $N)$ in our study was higher with those obtained by Anthofer and Kroschel [22].

In this study, C:N ratio for "Rongai" (13.2) was two units higher than for Velvet bean (10.2) during the wet season, but there was no significant difference. We assumed that is the main reason lower $\mathrm{N}$ concentration was found for Rongai during the wet $\left(39.7 \mu \mathrm{g} \mathrm{N} \mathrm{g}^{-1}(2.06 \% \mathrm{of} \mathrm{N})\right)$ season compared with dry season (53.5 $\mu \mathrm{g} \mathrm{N} \mathrm{g}^{-1}$ (2.78\% of $\left.\mathrm{N}\right)$ ) was due to their C:N ratio. Based on Jiménez et al. [25] findings, the $C: N$ ratio varies with plant species, age and is an effective indicator of the litter decomposition rate. Although we don't seem reasoning for finding higher C:N ratio (13.2) and higher $k$ rate (0.262) in Rongai during the wet season, it was expected to find low $k$ rate in presence of high $C: N$ ratio [26,27] or low $\mathrm{C}: \mathrm{N}$ ratio for our higher $k$ rate under wetter conditions. However, for the dry season, our results were more similar to the C:N values of 9:1 in mixture of leaves and stems of Velvet bean and 10:8 in shoots of "Rongai" reported by Ibewiro et al. [28]. 


\subsection{Soil Inorganic, Net Mineralization and Net Nitrification of $N$}

Soil inorganic $\mathrm{N}$ increased 5.8 times from day $22\left(138 \mathrm{mg} \mathrm{kg}^{-1}\right)$ to $90\left(795 \mathrm{mg} \mathrm{kg}^{-1}\right)$. Higher average value was observed at 90 DOI. However, there was no interaction between incubation days by legume species. Similarly, Odhiambo [24] found mineral N quantities increased with respect of incubation days. At the end of their experiment (118 DOI), mineral $\mathrm{N}$ was around 2.8 times higher than at 14 DOI. In addition, Odhiambo [24] found mineral $\mathrm{N}$ quantities of 96-134 and 92-108 mg N kg-1 in soils planted with "Rongai" and Velvet bean, respectively. In our study, most of the inorganic N was in the $\mathrm{NH}_{4}{ }^{+}-\mathrm{N}(82 \%)$ form. However, specifically for "Rongai", $50 \%$ of total inorganic $\mathrm{N}$ was in the $\mathrm{NO}_{3}{ }^{-}$-N at 22 DOI and decreased 7\% at 90 DOI. A study by Fosu et al. [9] reported 71.8 and 46.6, $55 \mathrm{mg} \mathrm{N} \mathrm{kg}^{-1} \mathrm{~N}$ (66 DOI) in Sunn hemp (Crotalaria juncea), Crotalaria retusa and Velvet bean, respectively. Unlike our experiment, they found that most of inorganic $\mathrm{N}$ was on $\mathrm{NO}_{3}{ }^{-}-\mathrm{N}$ form for all of the treatments. In addition, the concentration of $\mathrm{NH}_{4}{ }^{+}-\mathrm{N}$ was a $6 \%$ of total inorganic $\mathrm{N}$ at the beginning of the incubation study and decreased by $0.6 \%$ of the average by the end of study. They concluded that the low levels of $\mathrm{NH}_{4}{ }^{+}-\mathrm{N}$ indicated immobilization of $\mathrm{N}$ during the first 24 days of incubation. Sanclemente [29] reported that, in fields where Velvet bean was used as green manure, there was a reduction in mineralized $\mathrm{N}\left(103 \mathrm{mg} \mathrm{N} \mathrm{kg}^{-1}\right)$ in the soil. High clay soil content can reduce $\mathrm{N}$ mineralization [8]. For this reason, we can deduce that $\mathrm{N}$ mineralization occurred 90 days after incubation because the Coto soil series have a high clay content.

\section{Conclusions}

"Rongai" and Velvet bean DMY differed in the dry but not in the wet season $\left(>4000 \mathrm{~kg} \mathrm{ha}^{-1}\right.$ ) and both are excellent for use as cover crops. Both legumes enhanced inorganic $\mathrm{N}$ in an Oxisol, but, regardless of season, "Rongai" supplied nutrients to the soil faster than Velvet bean. "Rongai" having a higher decomposition rate than Velvet bean is most suited for fast growing row or vegetable crops in the tropics.

Author Contributions: R.T.-C. and E.V.-C. wrote the manuscript, and all the authors revised the manuscript. E.V.-C. designed the experiment. L.Y.L.-R. conducted the field sampling and analysis of the experimental work with the feedback from E.V.-C. and E.R.-P.

Funding: This research received no external funding.

Acknowledgments: We would like to acknowledge Delvis Pérez and Ricardo J. Goenaga, USDA-ARS Tropical Agriculture Research Station in Mayagüez for their assistance in soil and plant analysis.

Conflicts of Interest: The authors declare no conflict of interest.

\section{References}

1. Osorio, V. Descomposición y Liberación de Nitrógeno de Material Foliar y Radicular de Siete Especies de Sombra en un Sistema Agroforestal Con Café. Ph.D. Thesis, Universidad de Turrialba, Turrialba, Costa Rica, 2004.

2. Frankenberger, W.; Abdelmagid, H. Kinetic parameters of nitrogen mineralization of leguminous crops incorporated into soils. Plant Soil 1985, 87, 257-271. [CrossRef]

3. Skerman, P. Gramíneas Tropicales; Producción y Protección Vegetal; Colección FAO: Rome, Italy, 1991; Volume 23, pp. 1-730.

4. Flores, M. Velvet beans: An alternative to improve small farmers' agriculture. ILEIA Newsl. 1989, 5, 8-9.

5. Valenzuela, H.; Smith, J. Lablab. Sustainable Agriculture Green Manure Crops; Cooperative Extension Service, University of Hawaii: Manoa, HI, USA, 2002; 3p.

6. Palm, C.; Gachengo, C.; Delve, R.; Cadisch, G.; Giller, K. Organic inputs for soil fertility management in tropical agroecosystems: Application of an organic resource database. Agric. Ecosyst. Environ. 2001, 83, 27-42. [CrossRef]

7. Cobo, J.; Barrios, E.; Kass, D.; Thomas, R. Decomposition and nutrient release by green manures in a tropical hillside agroecosystem. Plant Soil 2002, 240, 331-342. [CrossRef] 
8. Myers, R.; Palm, C.; Cuevas, E.; Gunatilleke, I.; Brossard, M. The synchronization of nutrient mineralization and plant nutrient demand. In The Biological Management of Tropical Soil Fertility; Woomer, P.L., Swift, M.J., Eds.; John Wiley and Sons: Hoboken, NJ, USA, 1994; pp. 81-116.

9. Fosu, M.; Kühne, R.; Vlek, P. Mineralization and microbial biomass dynamics during decomposition of four leguminous residues. J. Biol. Sci. 2007, 7, 632-637.

10. Weber, M.A.; Mielniczuk, J. Estoque e diponibilidade de nitrogenio no solo em experiment de longa duracao. Rev. Bras. Cienc. Solo 2009, 33, 429-437. [CrossRef]

11. Cardoso, E.G.; Sá, J.C.D.M.; Briedis, C.; Ferreira, A.D.O.; Borszowskei, P.R.; Santos, J.B.; Baranek, E.J. Nitrogen dynamics in soil management systems: II-Mineralization and nitrification rates. Rev. Bras. Ciênc. Solo 2011, 35, 1651-1660. [CrossRef]

12. Rosolem, C.A.; Foloni, J.S.S.; Oliviera, R.H. Dinâmica do nitrogênio no solo em razão da calagem e adubação nitrogenada, com palha na superfície. Pesq. Agropecu. Bras. 2003, 38, 301-309. [CrossRef]

13. Sierra, J. Temperature and soil moisture dependence of $\mathrm{N}$ mineralization in intact soil cores. Soil Soil Biol. Biochem. 1997, 29, 1557-1563. [CrossRef]

14. Beinroth, F.; Engel, R.; Lugo, J.; Santiago, C.; Ríos, S.; Brannon, G. Updated Taxonomic Classification of the Soils of Puerto Rico; Bulletin 303; University of Puerto Rico, Mayagüez Campus, College of Agricultural Sciences Agricultural Experiment Station: San Juan, Puerto Rico, 2002; 38p.

15. Foss, T. The Determination of Nitrogen According to Kjeldahl Using Block Digestion and Steam Distillation; Application Note: Höganäs, Sweden, 2000; 11p.

16. Sparks, D. (Ed.) Methods of Soil Analysis. Part 3. Chemical Methods; SSSA Book Ser. 5; ASA abd SSA: Madison, WI, USA, 2007; 1309p.

17. Wieder, R. and Lang, G. A critique of the analytical methods used in examining decomposition data obtained from litter bags. Ecology 1982, 63, 1636-1642. [CrossRef]

18. Robertson, P.; Wedin, D.; Groffman, P.; Blair, J.; Holland, E.; Nadelhoffer, K.; Harris, D. Soil Carbon and Nitrogen Availability. In Standard Soil Methods for Long-Term Ecological Research; Robertson, P.G., Ed.; Oxford University Press: New York, NY, USA, 1999; pp. 259-271.

19. SAS. SAS/STAT User's Guide. (v. 8); SAS Inst. Inc.: Cary, NC, USA, 1999.

20. Colbert, R.; Valencia, E.; Beaver, J.S. Rendimiento de material seca y composición química de asociaciones de sorgo forrajero con leguminosas anuales. J. Agric. Univ. P. R. 2012, 96, 165-181.

21. Shehu, Y.; Alhassan, W.; Pal, U.; Phillps, C. The effects of intercropping Lablab purpureus L. with sorghum on yield and chemical composition of fodder. Agron. Crop Sci. 1999, 183, 73-79. [CrossRef]

22. Anthofer, J.; Kroschel, J. Above ground biomass, nutrients, and persistence of an early and a late maturing Velvet bean variety in the Forest-Savannah Transitional Zone of Ghana. J. Agric. Ecosyst. Environ. 2005, 110, 59-77. [CrossRef]

23. Poffenbarger, H.J.; Mirsky, S.B.; Weil, R.R.; Kramer, M.; Spargo, J.T.; Cavigelli, M.A. Legume proportion, poultry litter, and tillage effects on cover crops decomposition. Agron. J. 2015, 107, 2083-2096. [CrossRef]

24. Odhiambo, J. Nitrogen Mineralization of Green Manure Legume Residues in Different Soil Types. UC Davis: The Proceedings of the International Plant Nutrition Colloquium XVI. 2009. Available online: http:// escholarship.org/uc/item/1jr2m2h2 (accessed on 23 January 2011).

25. Jiménez, S.; Farfán, V.; Morales, L. Descomposición y transferencia de nutrientes de Cajanus cajan, Crotalaria juncea y Tephrosia candida como abonos verdes en cafetales. Cenicafé 2005, 56, 216-236.

26. Pereira, N.S.; Soares, I.; de Miranda, F.R. Decomposition and nutrient release of leguminous green manure species in the Jaguaribe-Apodi region, Ceara, Brazil. Cienc. Rural 2016, 46, 970-975. [CrossRef]

27. Wild, A. Mineralization of soil nitrogen at a savanna site in Nigeria. Exp. Agron. 1972, 8, 91-97. [CrossRef]

28. Ibewiro, B.; Sanginga, N.; Vanlauwe, B.; Merckx, R. Nitrogen contribution from decomposing cover crop residues to maize in tropical derived savanna. Nutr. Cycl. Agroecosyst. 2000, 57, 131-140. [CrossRef]

29. Sanclemente, O. Efecto del Cultivo de Cobertura: Velvet bean pruriens, en Algunas Propiedades Físicas, Químicas y Biológicas en un Suelo Typic Haplustalfs, Cultivado con maíz (Zea mays L.) en zona de Ladera del Municipio de Palmira, Valle. Ph.D. Thesis, Universidad Nacional de Colombia, Palmira, Colombia, 2009.

(C) 2018 by the authors. Licensee MDPI, Basel, Switzerland. This article is an open access article distributed under the terms and conditions of the Creative Commons Attribution (CC BY) license (http://creativecommons.org/licenses/by/4.0/). 